Fr. Jacek Froniewski*

Pontifical Faculty of Theology in Wroclaw

\title{
TOPICALITY OF THE SPIRITUAL HERITAGE AND THEOLOGY OF BROTHER ROGER OF TAIZÉ
}

This year in Wroclaw we experienced the European Youth Meeting organized by the Taizé Community. This great spiritual event is an opportunity to reflect more deeply on the importance of the heritage of Brother Roger of Taizé for the contemporary Church. As a starting point for this analysis, author took the biographical background, which will allow the reader to grasp the life context of Roger Schutz's ecumenical research. Then, in the following points, he describes three essential elements of Brother Roger's legacy, which are an ever-inspiring gift to the Church on the path of building unity. Firstly, it is a fully original form of Christian life in a monastic ecumenical community. Secondly, on the basis of this concrete experience of the Taizé Community, Brother Roger indicated a deeply existential way of building the unity of divided Christians. And thirdly, in his teaching he outlined a theology of forgiving love as the key to building reconciliation between the Churches. Undoubtedly the most spectacular fruit of his evangelical life are the crowds of young people from various Christian Churches that have invariably gathered around the Taizé Community for decades.

A few months ago we experienced the $42^{\text {nd }}$ European Youth Meeting in Wrocław, organized by the Taizé Community, which brought together 15 thou-

* Rev. Jacek Froniewski PhD - priest of the Archdiocese of Wroclaw, Master of Geography at the University of Wroclaw, doctor of dogmatic theology at the PWT in Wroclaw. After his doctorate he also studied three years of ecumenical theology at the Möhler-Institut für Ökumenik in Paderborn. Currently he is an assistant professor in the 1st Chair of Dogmatic Theology of the PWT in Wroclaw and lectures on dogmatic theology. In the years 2014-2017 he was Secretary General of the PWT. Currently, he is the Chancellor of the Wroclaw Metropolitan Curia. His main research interests are ecumenical theology and sacramentology. He has published over 20 academic articles and a book Teologia anamnezy eucharystycznej jako pamiatki uobecniajacej ofiare Chrystusa i jej implikacje ekumeniczne (Wrocław 2011); e-mail: abbajacek@o2.pl; ORCID: 0000-0003-0133-3125. 
sand young Christians from all over Europe, but also greatly involved about 100 local parishes and thousands of families hosting these pilgrims. It was a great celebration of faith and reconciliation both on the interdenominational plane and the international one. Such a meeting took place for the fifth time in Poland and the third time in Wroclaw. The phenomenon of these meetings organized either in the great cities of Europe, or in Taizé itself, where at a time of rapidly progressing secularization of the societies of our continent, tens of thousands of young Europeans gather for common prayer, gives a lot to think about, and therefore demands a certain theological reflection, not only in the field of pastoral theology. ${ }^{1}$ There is, therefore, a need to point out the sources of the power that attracts young people to the Taizé Community on a somewhat deeper level than just a fascination with the beauty of prayers, singing canons and the constant popularity of the many thousands of meetings organized by young people. It seems unquestionable that these sources should be seen above all in the life and teaching of the founder of the Taizé Community, Brother Roger of Taizé. ${ }^{2}$

So how do we see his person and legacy 15 years after his death? Although it still seems to be a relatively short perspective on the horizon of the Church's history, it is enough to assess the importance of his work from a certain distance. Especially for the young generation, he is already a historical figure, whose great charisma they constantly feel when coming to Taizé. So what elements of the spiritual heritage and theology of the founder of the Taizé Community can we regard as original and thus constantly topical and inspiring for the contemporary Church? The author, wanting to answer this question, realizes that this contribution is only a certain attempt to sketch out the issue, and much more to encourage some further in-depth reflection on Brother Roger's work, which actually still awaits a thorough theological study.

The basic research material here will be the writings of Brother Roger, and especially those that constitute the foundation sources for the Taizé Community. They are supplemented by studies, largely of a more historical and factual nature, since we still have very few strictly theological studies, and those that exist, are rather fragmentary in their scope and more often than not concern broadly defined spirituality or ecumenism and not systematic theology. Since this study, despite

One example is found in the ample publication: J. Höglauer, Der Einfluss von Taizé auf die Spiritualität Jugendlicher. Eine empirische Untersuchung, Berlin 2016 (pp. 384).

2 Such a conclusion can be drawn from a biographically rich interview with brother Marek, the first Pole in the Community, who in describing his 40 years of life in Taizé constantly refers to the person and teaching of his Founder - see Bóg. Cisza. Prostota. Brat Marek z Taizé w rozmowie z Piotrem Żyłka, Kraków 2019. Cf. Bóg przyjmuje wszystkich. Brat Alois z Taizé odpowiada na pytania młodzieży, transl. M. Cofta, Poznań 2009, p. 25-26. 
having a strong ecumenical leaning due to the specificity of the subject, is essentially theological in nature, the research has mainly used a theological-historical method consisting first of all in the analysis of sources, and then in the systematization of conclusions. As a supplement, the ecumenical method is used, which involves constructing a presentation open to the confessional multidimensionality of the theological truth, which is why we will often refer to the opinions contained in the works of non-Catholic authors. Here we should remember in particular the specificity of the ecumenical vocation of Brother Roger and his Community, which in its precursory form cannot in many respects be clearly classified in terms of classical Catholic ecclesiology. ${ }^{3}$

The formula of the article, in which we want to cover such a creative personality, with a wide range of activities, makes it necessary for this presentation to be reduced to only the four most important aspects. First, a concise biographical background will be presented, which, as a kind of introduction to further research, will allow us to grasp the life context of Brother Roger's pursuit. ${ }^{4}$ Next, we will focus our attention on the realization of his vocation to monastic life in the Taizé Community, focusing on the original elements of this work, especially in the ecumenical dimension. Another aspect, strongly correlated with the previous one, is the vision of how to build unity among divided Christians. In conclusion, we will attempt to diagnose his contribution to contemporary theology.

\section{BROTHER ROGER'S LIFE PATH}

Roger Schutz was born on May $12^{\text {th }} 1915$ in Provence ${ }^{5}$ (canton of Vaud) in French-speaking part of Switzerland, as the youngest of nine children of Charles Schütz, ${ }^{6}$ Pastor of the Reformed Church, and Amélie Marsauche, of French ori-

3 Cf. D. Sattler, Contributions by Brother Roger Schutz to Theology, in: Brother Roger's Contribution to Theological Thought. Acts of the International Colloquium Taizé, August 31 -September 5, 2015, Taizé 2016, p. 266-267.

4 The importance of this aspect of the study of the connection between the biographies of theologians and their teaching is highlighted by D. Sattler - ibidem, p. 267-268.

5 Biographical data based mainly on: S. Laplane, Frère Roger de Taizé. Avec presque rien..., Paris 2015 and J.-C. Escaffit, M. Rasiwala, Historia Taizé, Warszawa 2009; Bóg. Cisza. Prostota..., p. 61-104. See S.J. Koza, Schutz Roger, in: Encyklopedia katolicka, vol. 17, Lublin 2012, c. 1298-1299; J. Oeldemann, Schutz Roger, in: Personenlexikon Ökumene, Hg. J. Ernesti, W. Thönissen, Freiburg im Br. 2010, p. 206-208.

6 Roger's father had a German surname, Schütz, but after his marriage his wife of French origin, who did not like the German character of the surname, started using the spelling without umlaut. Official documents oscillated between both forms of writing. Today, the spelling Schutz is accepted - see S. Laplane, op. cit., p. 469, note 6. 
gin. Deeply rooted in the Protestant tradition and at the same time open family environment was the first place of his spiritual formation ${ }^{7}$ that was so important for the future path of the founder of Taizé. A great authority in his childhood was Roger's grandmother on the part of his mother Marie-Louise Marsauche, ${ }^{8}$ who during the First World War received refugees in the north of France and, as a Protestant, went to pray to the Catholic church to express her opposition to the absurdity of this bloody conflict between Christian nations. Years later, Brother Roger interpreted her inspirational influence on his life in this way:

The miracle of her life was that by reconciling the current of the Protestant-by-origin faith with the Catholic faith, she was able not to become a symbol of renouncing her own... My grandmother's intuition must have given me a Catholic soul in my childhood. ${ }^{9}$

At the end of his life he confirmed even more strongly the role of his grandmother's example in shaping his vocation:

When I was still very young, in turn, moved by the testimony of her life, I found my own Christian identity when I reconciled the faith of my ancestors with the mystery of the Catholic faith, without breaking communion with anyone. ${ }^{10}$

In 1931, Roger fell ill with difficult-to-cure tuberculosis. It was precisely this long-lasting disease that was for him a time to think deeply about his personal vocation. ${ }^{11}$

See G. Hammann, Did Brother Roger Have a Theology?, in: Brother Roger's Contribution to Theological Thought. Acts of the International Colloquium Taizé..., p. 18.

8 It should be mentioned here that her husband, Roger's grandfather, was in a Catholic seminary, which he left as a result of the controversies connected with the First Vatican Council, becoming an Old Catholic, and after his marriage he became a Reformed pastor - see D. Sattler, op. cit., p. 268.

9 F.R. de Taizé, Fleurissent les déserts du cœur, Taizé 1982, p. 75 (transl. after: J.-C. Escaffit, M. Rasiwala, op. cit., p. 12). See also Wybrać miłość. Brat Roger z Taizé 1915-2005, Poznań 2008, p. 21-23, 66; Brat Roger z Taizé, Bóg może tylko kochać, Warszawa 2005, p. 55. Cf. S. Laplane, op. cit., p. 19.

10 Brat Roger z Taizé, Bóg może tylko kochać..., p. 64. The current Priory of Taizé points out this path of Brother Roger as a constantly valid direction for the Community - Frère Alois, "Die Leidenschaft für die Einheit des Leibes Christi". Der Weg der Einheit, wie er in Taizé gelebt wird, Taizé 2012, p. 13 [Hefte aus Taizé 17]. See also Brat François, Czy Chrystus jest podzielony?, transl. M. Prussak, Poznań 2012, p. 15 [Zeszyty z Taizé 13].

11 See Brat Roger z Taizé, Bóg może tylko kochać..., p. 47. 
In accordance with his father's will, but contrary to his own passion for literature, he began studying Evangelical Theology in Lausanne and Strasbourg (1936-40). During his studies in Strasbourg, the 16th-century reformer Marcin Bucer became a very inspiring figure for him. As a theologian, he saw the need for small communities in the Church and, unlike Luther, he showed the way to reform as building unity, and considered this a central issue of theology. ${ }^{12}$ It was then that Roger's interest in monastic life developed, to which he dedicated his thesis Monastic Ideal before the times of St. Benedict and its conformity with the Gospel, ${ }^{13}$ defended in 1943. Such a subject of his work crowning his studies in Protestant theology proves that from his youth Roger fed his faith by drawing on various Christian traditions and breaking down denominational barriers. ${ }^{14}$

In August 1940, he had a break in his studies and cycled to France, conquered by the Nazis, with a view to finding a home where he could help the suffering and lead a lonely life of prayer. His choice finally fell on an old house in Taizé, a tiny Burgundy village in the deep province, $10 \mathrm{~km}$ from Cluny. And so, on 20 August 1940, the history of the future Taizé Community began. ${ }^{15}$ This location seems to have been largely determined by two factors: ${ }^{16}$ on the one hand, the proximity of Cluny with its great historical tradition of monastic life, and on the other hand, its location only about a dozen kilometres from the demarcation line separating the northern occupied part of France from the southern part under Vichy rule, which made it an excellent transfer point for fugitives from Nazi terror, especially Jews. ${ }^{17}$ At that time, the first draft of the future Rule of the Community was published on October 1, 1941 under the title Communauté de Cluny. Notes explicatives. ${ }^{18}$ It was also at this time that Roger established his first ecumenical contacts with the Catholic precursors of ecumenism: on July 4, 1941, Taizé was visited by Father Paul Couturier, and at the end of September 1942, the future Taizé Prior attended a meeting of the Ecumenical Group from Dombes, where he met the already then famous theologian Fr. Henri de Lubac.

\footnotetext{
See G. Hammann, op. cit., p. 20-22.

See more: J.-C. Escaffit, M. Rasiwala, op. cit., p. 26-28.

4 See W. Kasper, Mercy and the Ecumenical Journey of Brother Roger, in: Brother Roger's Contribution to Theological Thought. Acts of the International Colloquium Taizé..., Taizé 2016, p. 291.

15 Cf. S. Laplane, op. cit., p. 99-102.

16 Brother Roger often mentioned that the words of an old woman from Taizé, who had given him hospitality on the first day he arrived there in search of a home for the community, were decisive for him personally. - see J.-M. Paupert, Taizé i Kościót jutra, Warszawa 1969, p. 30.

17 See Wybrać miłość..., p. 27.

18 See fragments in: J.-M. Paupert, op. cit., p. 48-50.
} 
In mid-October 1942 Roger left for Switzerland and then found out that in November, after the German army had occupied the south of France, the Gestapo became interested in the house in Taizé ${ }^{19}$ He therefore decided to stay in Geneva and start implementing his concept of community life here. He was joined by Max Thurian, later Taizé Community theologian, ${ }^{20}$ Pierre Souvairan and Daniel de Montmollin. ${ }^{21}$ In the meantime Roger completed his studies and was ordained pastor of the Reformed Church on 16 July 1944. He gathered the experience of this time in a book Introdution à la vie communautaire published in October 1944. At the end of that month, Roger, Max and Pierre, and later Daniel, went to Taizé to finally realize there their monastic ideal, modelled on the Cluny spirit of prayer and work. Shortly after the war this small community took care of German prisoners and orphaned children. Soon another three companions joined and on Easter 1949 the first seven brothers took their profession ${ }^{22}$ for life, and the former Communauté de Cluny took the name Communauté de Taizé. Roger Schutz became its prior, and from then on always described himself as Brother Roger, while the brothers called him "our brother." Over the years this Protestant community took on a truly ecumenical character, when brothers from other denominations were also admitted to it - in 1961 the first Anglican and in 1969 the first Catholic. ${ }^{23}$

From the beginning, Brother Roger wanted the Taizé Community to be involved in building reconciliation between divided Christians. In the fifties and sixties Taizé was the site of numerous official and unofficial ecumenical meetings. $\mathrm{He}$, too, established many personal ecumenical contacts. However, as he often stressed, the meeting with Pope John XXIII, who confirmed the Taizé Community in its vocation to build Christian unity, was for him a breakthrough. This Pope invited Brothers Roger and Max to participate in the Second Vatican Council as observers. $^{24}$

Since the end of the 1950s, more and more young people from all over the world started coming to Taizé. This was a new challenge for the brothers. In 1970,

19 See Bóg. Cisza. Prostota..., p. 66.

20 See more systematic development of Max Thurian's theology with a detailed bibliography of all his publications, but only until 1970 - H. Fox, Die Theologie Max Thurians, Trier 1971. Cf. D. Sattler, op. cit., p. 275.

21 He's the only brother in this group who is still alive. (He is 98 years old) - Bóg. Cisza. Prostota..., p. 88 .

22 The term 'profession' has been used precisely to emphasise the reference to monastic tradition - see S. Laplane, op. cit., p. 166-167; for the formula of profession taken then see ibidem, p. $174-175$.

23 See J.-C. Escaffit, M. Rasiwala, op. cit., p. 176.

24 See Brat Roger z Taizé, Bóg może tylko kochać..., p. 64-67. The fruit of the participation in the Council was the commentary of these brothers on the Constitution Dei Verbum (R. Schutz, M. Thurian, La Parole vivante au Concile, Taizé 1966) - see more D. Sattler, op. cit., p. 275-277. 
Brother Roger announced the "Youth Council," which began in $1974{ }^{25}$ with the gathering of 40,000 young people, and was later replaced by a "pilgrimage of trust on the Earth" which has continued until now. ${ }^{26}$ The youth meetings organized by the Community, first at its seat and then in the great cities of Europe and other continents, have even become the hallmark of Taizé. Thanks to them, the way the Community prayed and the idea of reconciliation spread throughout the world. Brother Roger shared his thoughts with the young people in letters prepared in various parts of the world marked by difficult experiences, and they were written each year for successive youth meetings and provided material for group sharing in Taizé. The Prior of Taizé also published many books containing his meditations, prayers and diaries. ${ }^{27}$

Undoubtedly the great mark of a recognition of the importance of the work of Brother Roger and his Community was the visit of Pope John Paul II to Taizé on 5 October 1986. The words of the Polish Pope spoken in the Church of Reconciliation are significant: "The Pope, like you pilgrims and friends of the community, came here for a while, but one comes to Taizé as if to the source." But even more strongly John Paul II supported the community in its vocation in the words to the brothers,$^{28}$ which one of them commented on: "To explain to someone the meaning of the vocation of the community, it is enough to give them to read the words of the Pope. This is the best introduction to our life." ${ }^{29}$ The recognition of Brother Roger's contribution to reconciliation and youth work was also evidenced by prizes of international prestige: the Templeton Prize (1974), the UNESCO Prize for Education to Peace (1988), the Charlemagne Prize (1989), the Robert Schumann Prize (1992). Also in Poland, his ecumenical commitment was appreciated by the honorary doctorate of ATK in Warsaw (1986). ${ }^{30}$

At the age of 83, Brother Roger officially named Brother Alois as his successor. He was a German Catholic who had been a member of the Community since 1974 and was to become its prior after the founder's death. ${ }^{31}$ And the death came

25 See more Préparer le concile des jeunes. Audacieuse aventure, Taizé 1973.

26 Cf. Wybrać milość..., p. 48-51.

27 Full bibliography - see ibidem, p. 141-142. Cf. S.J. Koza, op. cit., k. 1299. And the full bibliography concerning Taizé - A. Łopalewski, Taizé przypowieścia o komunii i pojednaniu. Formacja chrześcijańska wspólnoty z Taizé, Lublin 2011, p. 141-145.

28 See Brat Roger z Taizé, Miłość ponad wszelka miłość. Źródła Wspólnoty z Taizé, Poznan 1991, p. $98-101$.

29 Papież Jan Pawet II $w$ Taizé, Taizé 1986, p. 6 (a leaflet published for young people arriving in Taizé).

30 See the laudation on this occasion in: A. Skowronek, Odkrywanie jedności, Warszawa 1988, p. $110-117$.

31 Cf. Bóg. Cisza. Prostota..., p. 346-347. 
unexpectedly - on August 16, 2005, during an evening prayer, Brother Roger was stabbed by a mentally ill woman from Romania.

\section{THE PHENOMENON OF TAIZÉ AS A MONASTIC COMMUNITY}

Brother Roger's charism is the basis of the phenomenon associated with the name of Taizé, but this work finds its lasting strength in the Community he founded. ${ }^{32}$ In order to understand the incredible originality of the Taizé Community, one must first realize that on the Protestant ground, religious life practically disappeared after the Reformation. ${ }^{33}$ The radical criticism of this form of Christian life made by the Reformers ${ }^{34}$ meant that for over 300 years no one dared to debate on this matter. The sharpness of this criticism was directed mainly against the religious vows, which were in a way supposed to guarantee the justification for deeds, and not by grace itself through faith, which contradicted the fundamental principle of Protestantism sola gratia. ${ }^{35}$ However, since the middle of the $19^{\text {th }}$ century, groups of deaconesses ${ }^{36}$ who lived together began to appear in Protestantism and after World War II they also took religious vows - Roger met such a community in Grandchamp in autumn 1940. ${ }^{37}$ Further inspiration for the concept of the Taizé Community was also provided by an experiment, operating in the years 1935-37 in Finkenwalde (now Szczecin-Zdroje), a seminar for pastors founded by Dietrich Bonhoeffer - an outstanding Lutheran theologian. The pioneering character of this centre in the Protestant world consisted in the implementation of community life it was a peculiar quasi-religious fraternity house, where the essential elements of

32 Cf. Brat Roger z Taizé, Bóg może tylko kochać..., p. 25.

33 See L. Schlumberger, Can One Be Protestant and a Monk?, in: Brother Roger's Contribution to Theological Thought. Acts of the International Colloquium Taizé..., p. 90-91 - The author indicates here few examples of forms of common life among the Protestants between the 16th and 18 th centuries.

34 See Wyznanie augsburskie, art. XXVII oraz Obrona Wyznania augsburskiego, art. XXVII, in: Księgi Wyznaniowe Kościoła Luterańskiego, Bielsko-Biała 1999, p. 156-158 oraz 313-322. In 1521 Luther wrote a separate treaty in 139 points criticizing the religious vows De votis monasticis Martini Lutherii judicium (WA 8, 323-329) - German text: Ein Urteil Luthers über die Klostergelübde, in: Luther deutsch. Die Werke Martin Luthers in neuer Auswahl für die Gegenwart, Hg. K. Aland, Göttingen 1991, Bd. 2, p. 313-322. Cf. J.-M. Paupert, op. cit., p. 55-56.

35 See more L. Schlumberger, op. cit., p. 92-94, 97. An echo of this view can also be found in the text of the Rule of Taizé: "You know that salvation is provided only by the grace of our Lord Jesus Christ; therefore do not impose asceticism on yourself for its own sake" - Brat Roger, Reguta. Listy i modlitwy, [no place of publ.] 1981 (mimeograph), p. 6.

36 See more L. Schlumberger, op. cit., p. 100-103.

37 See J.-C. Escaffit, M. Rasiwala, op. cit., p. 20-21; S. Laplane, op. cit., p. 106-107. 
life were: everyday common meditation, the custom of personal confession - long abandoned in Lutheranism as well as common finances. ${ }^{38}$ However, Roger Schutz modelled the ideal of monastic life itself directly on the experiences of two centres of renewal of monasticism, which had once been extremely important in the history of the Church and radiated across Europe, and which were located in the immediate geographical proximity of Taizé - the Benedictine Abbey of Cluny and the Cistercian Abbey of Citeaux..$^{39}$

The first outline of the rule for the future community was sketched by its founder in the 1941 publication Communauté de Cluny. Notes explicatives, where as the fundamental axis of building a fraternal community he indicated a life in the spirit of Beatitudes: joy, simplicity, and charity, which would become a permanent feature of formation in Taizé ${ }^{40} \mathrm{He}$ then developed his idea of community life in the book Introdution à la vie communautaire of 1944, mentioned above. The first version of the Rule of Taizé was written at the turn of 1951/52. ${ }^{41}$ Its text evolved later on - for the $40^{\text {th }}$ anniversary of the Community, the renewed version of the Rule took the name Little Source of Taizét2 and the next one was preceded by a series of texts by Brother Roger, which formed the entire Taizé Community Sources. ${ }^{43}$ The evolving text of the Rule, though unchanged as to its essence, became in its form more and more a poetic meditation on the Gospel applied to community life. ${ }^{44}$ It never had the character of some religious constitutions, and was rather a set of basic intuitions of Brother Roger based on the Gospel, expressing his vision of the Community, formulated with great simplicity. In a certain way, the Rule was treated by its author as a certain provisional text open to the constant inspiration of the Holy Spirit - as he wrote in one of its earlier versions:

If this rule were to be treated as something closed and complete, and if it should relieve us of our ever-increasing pursuit of God's purposes, the love of Christ and the light

38 See more D. Bonhoeffer, Życie wspólne, Kraków 2001.

39 Cf. A. Łopalewski, op. cit., p. 74-75.

40 Cf. M. Grygiel, Taizé, in: Encyklopedia katolicka, vol. 19, Lublin 2013, c. 448.

${ }^{41}$ Brother Roger presented it to the brothers at Easter 1952. - see S. Laplane, op. cit., p. 192-193. The entire text of the original rule in the Polish translation see J.-M. Paupert, op. cit., p. 237-266.

42 Reguta zwana ,mate źródto" Taizé, no year of (mimeograph published by the Community of Taizé). Cf. Brat Roger, Reguła. Listy i modlitwy..., p. 5-46.

43 See Brat Roger z Taizé, Miłość ponad wszelka miłość..., and idem, Źródła Taizé. Bóg chce naszego szczęścia, Poznań 2001.

44 After the death of Br. Roger, the Community returned to the original Rule of the early $1950 \mathrm{~s}-$ see more Bóg. Cisza. Prostota..., p. 80. 
of the Holy Spirit, it would mean that we took on an unnecessary burden; it would be better if it was never written. ${ }^{45}$

The Rule is accompanied by the text of the profession of the evangelical counsels called "Commitment for life." ${ }^{46}$ It is worth noting that the Rule of Taizé does not use the term "perpetual vows" anywhere. ${ }^{47}$ Brother Roger initially hesitated for a long time to introduce some form of religious vows, due to fears of being misunderstood in the Protestant milieu. ${ }^{48}$ However, it was already clear to the first friars that the decision to form a permanent community together must involve a commitment for life and they made such commitments in $1949 .{ }^{49}$ The text of the Commitment consists of an encouragement, which is a collection of evangelical indications and appropriate promises in the form of six questions that define the commitments made. Among them, we find three classical religious vows, which are described in slightly different terms, so that they are not historically burdened by the Protestant-Catholic controversy concerning the understanding of these vows as some form of merit: ${ }^{50}$ renunciation of property and community of goods, celibacy and acceptance of the decisions of the community expressed by the servant of communion, as the Rule defines the Prior. It is worth noting that Brother Roger preferred the word simplicity over poverty. In the older version of the Rule, it was even written "Poverty is not a value in itself". ${ }^{51}$ The founder of Taizé explained his own concept of evangelical poverty in the Rule: "The spirit of poverty is not about making oneself poor, but about arranging everything in life with ingenuity in accordance with the simple beauty of creation." ${ }^{52}$ The radicalism of living poverty in this sense is realized in Taizé not only by living from the work of one's own hands, but also by the principle of absolute non-acceptance of any goods - donations, inheritances or even gifts, as the Rule comments on this: "The courage of not supplying oneself with any capital, free from the fear of possible poverty, gives a calm strength." ${ }^{53}$

The rhythm of life in Taizé is determined by common prayer, for which the brothers together with the pilgrims who come to them gather in the Church of Reconciliation three times a day. As we read in an earlier version of the Rule:

5 Brat Roger, Reguła. Listy i modlitwy, op. cit., p. 39. Cf. Wybrać miłość..., p. 8.

46 See idem, Źródła Taizé..., p. 80-82.

47 See more L. Schlumberger, op. cit., p. 98-99.

48 See Br. Roger's statement on this subject - ibidem, p. 99, note 12.

49 See J.-C. Escaffit, M. Rasiwala, op. cit., p. 40-41.

50 Cf. L. Schlumberger, op. cit., p. 99.

$51 \quad$ Brat Roger, Reguła. Listy i modlitwy ..., p. 31.

52 Idem, Źródła Taizé..., p. 70.

53 Ibidem. 
"The regularity of common prayer makes the love of Jesus germinate in us, even though we do not know how." 54 The form of this prayer has changed throughout the history of the Community. Originally it was modelled on the Benedictine liturgy combined with elements taken from the traditions of French Protestantism. With the influx of young people, it required a certain simplification and was based on simple meditative chants with verses repeated many times, which are now known throughout the world as the canons of Taizé, and its center is the reading of the Word of God and a long moment of silence. This so-called "Taizé prayer" has now become a kind of common ecumenical good of all Christian Churches, and is commonly encountered all over the world on many occasions, especially during various types of ecumenical services. ${ }^{55}$

The fundamental aim of the Taizé Community is to put into practice the "parable of community," ${ }^{56}$ or as Brother Roger later put it the "parable of communion," which was very aptly formulated by the Orthodox theologian Olivier Clément:

The word 'parable' introduces humility: the brothers do not claim that the community is the full realization of ecclesial communion, but that it is a 'parable.' What image of the Church is the parable to which the community is called? It is supposed to be precisely the image of the Church, gathered in her diversity. ${ }^{58}$

This diversity in the Community has a concrete ecumenical dimension - it is currently made up of about 100 brothers from different ecclesiastical traditions: about half of them are Protestants and Anglicans and the rest are Catholics. They also come from very different cultures - they represent nearly 30 countries from four continents. Brother Roger never planned for the Taizé Community to grow too much - to open new foundations; on the contrary, he wanted it to remain a single genuine small family, so that the brothers who form it would realize reconciliation in the concrete unity of the visible community. Yes, since the beginning of the 1950s some brothers have lived in several so-called fraternities in different parts

${ }_{54}$ Brat Roger, Regula. Listy i modlitwy..., p. 11.

55 See S. Kopp, Liturgie und Ökumene aus katholischer Perspektive, "Catholica" 72 (2018) 1-2, p. 125. Cf. C. Sigov, Vulnerable Trust and the "New Song" of Taizé, in: Brother Roger's Contribution to Theological Thought. Acts of the International Colloquium Taizé..., p. 187-189; W. Kasper, A Handbook of Spiritual Ecumenism, New York $2008^{3}$, p. 86.

56 Brat Roger z Taizé, Źródła Taizé..., p. 81. The term was first used by Br. Roger in 1969 - see S. Laplane, op. cit., p. 159.

57 Brat Roger z Taizé, Źródła Taizé..., p. 58.

58 O. Clément, Taizé, szukanie sensu życia, Poznan 1999, p. 31 - it is worth noting this publication, as it seems to be one of the deepest in showing what Taizé really is - see the opinion in: Frère Alois, op. cit., p. 15. 
of the world, but these are something provisional and their goal is to experience life together with the poorest. ${ }^{59}$ The phenomenon of the Taizé Community can therefore be recapitulated as an original combination of elements of the monastic tradition with the pioneering intuitions of Brother Roger, ${ }^{60}$ but both of these elements reach one source - they are deeply rooted in the Gospel. It is, according to the term of John Paul II, a community with "a particular, original and even in a sense provisional vocation." ${ }^{1}$

\section{THE BUILDER OF UNITY BETWEEN CHRISTIANS}

"Never accept the scandalizing fact of Christians being divided, who so eagerly profess the love of their neighbor, yet remain divided. Fervently love the unity of the Body of Christ" ${ }^{\prime 2}$ - these words of Brother Roger inscribed in the Rule of the Taizé Community seem to be the best summary of his life. The tireless search for ways to reconcile the divided Christians was a particular charism of Brother Roger. He imparted it not only to the Taizé Community he founded, but also successive generations of young people who came there in search of the sources of faith. It can even be said that this Community in its essence, starting from Brother Roger's first projects, was to be the site of a very concrete realization of this desire - as a "parable of communion" it was to make the reconciliation of Christians visible right now. ${ }^{63}$ From the beginning he believed in the power of witness of such a community because, as he wrote in his letter The Ways of a Pilgrim: "if such a community becomes a leaven of reconciliation in that communion which is the Church, then the impossible becomes possible." ${ }^{64}$ The turning point in the practical implementation of this vocation by the community was the acceptance of the Catholic brothers - as Brother Roger said: "the presence of the Catholic brothers among us forced us to be concrete, to reject answers that would be purely

59 See Brat Roger z Taizé, Źródta Taizé..., p. 62; Bóg. Cisza. Prostota..., p. 235-239-currently, Brother Alois has introduced a year-long stay in the fraternity as a permanent element of formation for young brothers before their vows. Cf. A. Łopalewski, op. cit., p. 78, note 194.

60 See more Brother Alois Prior of Taizé, What Is Distinctive about Taizé?, in: The Relevance of a Religious or Monastic Vocation. Acts of the International Colloquium, Taizé, 5-12 July 2015, Taizé 2016, p. 13-19.

${ }_{61} \quad$ See Brat Roger z Taizé, Źródła Taizé..., p. 85.

62 Brat Roger, Regula. Listy i modlitwy..., p. 9.

63 See Wybrać miłość..., p. 69; Frère Alois, op. cit., p. 14.

64 Brat Roger, Regula. Listy i modlitwy..., p. 75. 
theoretical." ${ }^{65}$ Thus a concrete consequence of this fact was the decision taken in the late 1960s and early 1970s to receive the Catholic Eucharist in the Community and to recognize the necessity of the ministry of the Bishop of Rome for the unity of the Church. ${ }^{66}$

Referring to this chronology, we can, somewhat generalizing, distinguish two essential stages in the way of the ecumenical involvement of Brother Roger and the Taizé Community. In the nineteen-fifties and sixties this was largely an activity in the institutional sphere, that is, participation in forums of ecumenical dialogue, organizing meetings for theologians and those responsible from the various Churches, and finally, participation in the Second Vatican Council. In this field the outstanding contribution made by Brother Max Thurian to the theological work of the Dombes Group and of the Commission "Faith and Order" of the World Council of Churches should be highlighted. ${ }^{67}$ Later we see in the activities of the Community concerning Christian unity a certain shift in emphasis, albeit without abandoning theological activity, more towards spiritual and practical ecumenism - reconciliation was based much more on building direct human relations. The key to restoring unity here is a real encounter as a method of breaking down distrust and barriers through the experience of being together - knowing each other and mutual sharing of one's gifts. Taizé has thus become a meeting place on a large scale, mainly for young people from different countries as well as from different denominations, where prayer and meditation on the Bible was a common platform. ${ }^{68}$ This experience of meeting people of different origins in the communion of the Church has become a special feature of Taizé and a magnet that attracts larger and larger groups of people. Brother Roger's prophetic vision of a small community as an evangelical leaven of unity began to bear concrete fruit, albeit unexpectedly, because the founder of Taizé had never planned that it would be a place of big gatherings for young people. Nor did the Taizé Community, despite the rapid influx of young people, ever want to formalize this in the form of creating some new movement in the Church. Thus fidelity to the original charism of building Christian unity, through the authenticity of the

65 Brat Roger przeor Taizé, Niech twoje święto trwa bez końca. Zapiski (1969-1974), Warszawa 1982, p. 50.

66 See more Frère Alois, op. cit., p. 15-18. Cf. Brat Francis, op. cit., p. 16-17; D. Sattler, op. cit., p. $277-278,281$.

67 See more J. Froniewski, Teologiczne znaczenie wkładu Maxa Thuriana w przygotowanie "Dokumentu z Limy (BEM)" w zakresie eucharystycznego charakteru anamnezy (z pozycji 30 lat recepcji Dokumentu), "Wrocławski Przegląd Teologiczny" 20 (2012) 2, p. 84-86; M. Hardt, Thurian Max, in: Personenlexikon Ökumene..., p. 225-226 (here also bibliography in German); J.-C. Escaffit, M. Rasiwala, op. cit., p. 26, 31-32, 34, 36, 42-43, 52-53, 61, 130-132.

68 See more J. Höglauer, op. cit., p. 73-128. 
testimony of the life of the Community, gave rise to a completely new gift - it brought to Taizé thousands of young people, thirsty for an experience of a life of prayer and community, often full of an unconscious longing for Christ in the communion of the Church.

The more Brother Roger approached the end of his life, the more he felt that on the road to Christian reconciliation, in view of the slowdown in the process of official ecumenical dialogue, strong prophetic gestures were needed instead of waiting for further theological documents. This is attested to by his courageous text, addressed a year before his death to the young people gathering at the meetings held by the Taizé Community:

For many years the ecumenical vocation has been a stimulus for important conversations. It is an announcement of living communion between Christians. [...] Could there in the Church appear signs of great openness, so great that one could say: those who were divided in the past are no longer separated, they live in communion? The first step towards reconciliation will be to see those places all over the world where life in communion is already being realized. It will take courage to say this and to adapt to it. The texts will come later. Does the privileged treatment of the texts not result in putting away the call of the Gospel: reconcile with your brother without delay? ${ }^{69}$

These words of the founder Taizé are not so much an expression of impatience as an expression of evangelical radicalism in the sense of reconciliation inscribed from the beginning in the vocation of the Community. Reconciliation for Brother Roger is something concrete, it is faithfulness to the Gospel and its practical realization:

In this unique communion that is the Church, old and new disputes tear Christ apart in His Body. The great ecumenical vocation is, and always will be, the realization of reconciliation without delay. According to the Gospel, reconciliation should not be postponed: "So if you bring your gift before the altar and there you remember that your brother has something against you, leave your gift there before the altar and first go and reconcile with your brother." "Go first!" And certainly not: "Put it off!" Ecumenism sustains false hopes when reconciliation is postponed. It stops at a standstill and even becomes petrified when it allows for parallel paths to be created where forgiveness loses its life-giving power ${ }^{70}$.

69 Brat Roger z Taizé, Uźródet radości. List 2004, Taizé 2004, p. 4.

70 Brat Roger z Taizé, Źródta Taizé..., p. 28. Cf. idem, Bóg może tylko kochać..., p. 61; idem, Jego miłość jest ogniem, transl. A. Foltańska, Katowice $1992^{2}$, p. 89-91. 
Interpreting these words in the context of the entire Brother Roger's life, we can state today that his work has become a prophetic sign for the divided Christians at the turn of the twentieth and twenty-first century, because he did not only think so, but actually lived in this way. This was not just outlining beautiful ideas - he completely devoted his life to the evangelically radical realization of the work of Christian reconciliation.

What should be emphasized in particular is that Brother Roger always wanted to create his work in the Church, not above her or in opposition to her. The communion of the Church is one of the key concepts in his writings and a great desire of all his life - as he wrote: "«Communion» is one of the most beautiful names of the Church." ${ }^{71}$ Hence his attachment to building up direct ties, especially with the heads of the various Churches and, above all, with the Pope, which has been repeatedly perceived negatively in many Protestant circles, even raising suspicion of a crypto-conversion to Catholicism. ${ }^{72}$ However, the founder of Taizé always looked for a vision of the Church that would not consist in renouncing one's own roots, but would also not be falling into syncretism. It is true that in Taizé we find elements of both the Protestant and Anglican traditions, as well as the Catholic and Orthodox ones, but it is about the reintegration and reconciliation of these traditions, because the Community of Taizé as a "parable of communion" wants to be the leaven of the undivided Church. And the undivided Church, as O. Clément writes, is the Church of Pentecost, and that is why at Taizé one can experience a kind of "Pentecostal harmony," but this is not so much about a historical return to the undivided Church of the first centuries as it is about the reality of today, in which the Holy Spirit makes this ecclesial communion real in an experience of Pentecost that transcends all past divisions. ${ }^{73}$ And in this sense Brother Roger's work in the form of the Taizé Community can be called "the place of the prophetic Church." 74 It is not a ready-made ecclesiological concept of the "Church of tomorrow" to which Taizé never had the slightest intention of aspiring, but more an evangelical intuition which Brother Roger sowed to indicate how to move forward towards unity. The current Prior of Taizé writes:

Brother Roger's path should be carefully considered in order to understand it correctly. We still have not quite discovered how it can be made more concrete. By following it,

${ }^{71}$ Wybrać miłość..., p. 67. Cf. Brat Roger z Taizé, Miłość ponad wszelka miłość..., p. 29.

72 See J.-C. Escaffit, M. Rasiwala, op. cit., p. 132-134. Cf. W. Kasper, Mercy and the Ecumenical Journey of Brother Roger..., p. 294.

73 O. Clément, op. cit., p. 31-32. Cf. W. Kasper, Mercy and the Ecumenical Journey of Brother Roger..., p. 292-293.

74 J.-C. Escaffit, M. Rasiwala, op. cit., p. 167. Cf. D. Sattler, op. cit., p. 281-282. 
we want to anticipate reconciliation through our life in Taizé and already live as reconciled. We hope that through this experience we will contribute to the preparation of theological progress. Is it not always the case in the history of the Church that the faith put into practice precedes theological formulations? ${ }^{75}$

\section{THEOLOGY WRITTEN BY THE HEART}

Brother Roger left us with about a dozen books, ${ }^{76}$ but we do not find any treatises that systematically address theological issues. These are, apart from the successive versions of the Rule of the Taizé Community, rather loose thoughts, albeit solidly based on the Bible and referring to the Fathers of the Church, most often collected in the form of diaries, notes or meditations. ${ }^{77}$ Besides, his legacy includes a whole series of deeply meditative annual letters written to young people, ${ }^{78}$ which are the basis for work at meetings organized by the Community. Therefore, some have accused him of a lack of substantive theological reflection. ${ }^{79}$ What is more, he himself, especially in the early period of his life, was quite critical of academic theology and we even find once in his notes surprising words - as for a graduate of the Faculty of Theology: "I never liked theology." ${ }^{\circ 0}$ Brother Alois explains this statement in such a way that it did not mean disregarding theology, but the urgent need to put it into practice - the priority of the living dimension of faith over the conceptual one. ${ }^{81}$ Yet, for the sake of completeness, it should be recalled that the founder of the Taizé Community constantly sought inspiration on his path in close encounters with such eminent theologians as: de Lubac, Congar, Kasper, Ricoeur or Clement.

75 Frère Alois, op. cit., p. 16.

76 Since 2011, the publishing of Brother Roger's collected works in Taizé began - by the end of 2019, eight volumes see http://www.taize.fr/pl_article10857.html?territ=10\&category=1\&lang=pl [accessed 13.04.20] (since 2016, Herder in German has only published volume I).

77 See more on the sources for research on the theology of Br. Roger - D. Sattler, op. cit., p. 272-275.

78 The full list is on website: https://pl.wikipedia.org/wiki/Roger_Louis_Sch\%C3\%BCtz-Marsauche [accessed 13.04.20].

79 Cf. G. Hammann, op. cit., p. 17; Wybrać miłość..., p. 132.

80 „Je n'ai jamais aimé la théologie" (sententce written in 1948.) - Frère Roger de Taizé, À la joie je t'invite. Fragments inédits 1940-1963, Taizé 2012, p. 21 (Les écrits de frère Roger, vol. 2). See also G. Hammann, op. cit., p. 17 and 24.

81 Brother Alois Prior of Taizé, In Conclusion, in: Brother Roger's Contribution to Theological Thought. Acts of the International Colloquium Taizé..., p. 299-300. Cf. G. Hammann, op. cit., p. 19, where he points to the inspiration coming from M. Luther, who stated: Sola experientia facit theologum and Vera theologia est practica - ibidem, p. 22; D. Sattler, op. cit., p. 272. 
If we penetrate really deeply into the work of the founder of Taizé, regardless of these various objections, we discover that he undoubtedly deserves to be called a theologian, but perhaps rather in the original sense of the term, as one who has the gift of explaining the mysteries of faith, because in the $20^{\text {th }}$ century, there are not many spiritual authorities like him who would speak about God and His love with equally great simplicity and at the same time with such power of persuasion. Hence Brother Roger, more than as a theologian in the modern sense, that is, as someone doing a methodical reflection on Revelation, should perhaps be seen as a prophet in the biblical sense, one who paves new paths for God in the world. ${ }^{82}$

However, in such interpretation, can his teaching, as it is usually done, be reduced to the sphere of spirituality or even mysticism, or can it be encapsulated only within the framework of ecumenical research and mainly on the level of spiritual ecumenism? At the end of August 2015, on the occasion of the $100^{\text {th }}$ anniversary of Brother Roger's birthday and $10^{\text {th }}$ anniversary of his death, an international scientific colloquium entitled Brother Roger's Contribution to Theological Thought was held in Taizé, bringing together 250 young theologians of various denominations from many countries of the world, with 20 papers showing Brother Roger's contribution to a wide range of different fields of theology. ${ }^{83}$ This symposium clearly showed, perhaps for the first time in such a vast area, that Brother Roger's legacy can become a very inspiring locus theologicus for theological research. It is difficult to present here all the results of the studies on the thought of the founder of Taizé, which were collected in a publication totalling 300 pages, but it is worth sketching out the main lines in his teaching, which bring some clear freshness to the theological thinking of our time. Cardinal Walter Kasper, an eminent theologian and retired President of the Pontifical Council for the Promotion of Christian Unity, who also took part in this debate and it is his text that crowns the collection of speeches from this conference will be a competent guide in sketching this outline of the fundamental elements of the contribution of Brother Roger's teaching to contemporary theology.

Cardinal Kasper, who knew Brother Roger and his Community ${ }^{84}$ well from the time when he was still a professor of theology in Tübingen, calls the founder of Taizé an existential theologian, that is, a theologian whose life was rooted in a

82 Cf. W. Kasper, Mercy and the Ecumenical Journey of Brother Roger..., p. 286; D. Sattler, op. cit., p. 266. In such a tone also Bishop Jorge Ortiga - chairman of the Portuguese Episcopal Conference wrote about the founder of Taizé after his death - see Wybrać miłość..., p. 23.

83 Brother Alois Prior of Taizé, Presentation, in: Brother Roger's Contribution to Theological Thought. Acts of the International Colloquium Taizé..., p. 11-12.

84 It is worth reminding here that it was Card. Kasper himself who presided in Taizé over the funeral mass of Brother Roger 23 August 2005. 
deep spiritual experience; a theologian who listened on his knees in silence to the voice of God and lived what he heard in his heart to open the paths of hope and reconciliation. ${ }^{85}$ The key word that constantly returns in Brother Roger's statements, prayers and writings is trust, trust of the heart. What is worth emphasizing is precisely this element of the message proclaimed at Taizé, which most young people who come here in search of the sources of faith rediscover for themselves as something fundamental to establishing a living relationship with God. This trust, as Brother Roger teaches, is always possible, even in the darkness of our existence, when we turn to the Risen Christ. ${ }^{86}$ What gives this trust a permanent foundation is the basic biblical truth that God is love, which in various ways returns as the constant leitmotiv of all the texts of the first Prior of Taizé. As Brother Roger repeated until his death "God can only love." ${ }^{87}$ The Protestant theologian Gottfried Hammann even claims that this theology of God's love, interpreted more with the heart than with reason, can be called the "theology of agape." 88 God in this love is faithful to himself and to us, and the essence of this love is mercy. As Kasper writes, mercy is the basic truth about God in Brother Roger's teaching, and the concrete expression of this is forgiveness as an opportunity for a new beginning. ${ }^{89}$ What is more, God in his mercy is always patient - He always accompanies us on our life's paths..$^{90}$

This message of God's love and mercy, which enables us to trust in every situation, is not, in Brother Roger's view, a utopia or an abstract idea. In Kasper's opinion, it translates very specifically into ecclesiology. God, by revealing these truths to us through His incarnate Son, continues to make them real in His Body - the Church - after His resurrection: "After His resurrection, the presence of Christ became something concrete in the communion of love that is the Church." The Church as a "communion of love" - as the Founder of Taizé prefers to call

85 W. Kasper, Mercy and the Ecumenical Journey of Brother Roger..., p. 286.

86 Ibidem, p. 287-288. Cf. W. Kasper, That They May All Be One. The Call to Unity, London-New York 2004, p. 164, where he points to the Christological criterion as a basis for authentic spiritual ecumenism.

87 The essence of this teaching can be found in the original 2002 collection: Brat Roger z Taizé, Bóg może tylko kochać. Cf. K. Scott, Experiencing and Thinking Jesus, in: Brother Roger's Contribution to Theological Thought. Acts of the International Colloquium Taizé..., p. 122-127. G. Hammann, op. cit., p. 23.

89 See in particular the chapter "Przyjąć przebaczenie", in: Brat Roger z Taizé, Bóg może tylko kochać..., p. 42-43; ibidem, p. 95-96, 101. Cf. idem, Jego miłość jest ogniem..., p. 16-18.

90 See W. Kasper, Mercy and the Ecumenical Journey of Brother Roger..., p. 288-289. Cf. idem, Barmherzigkeit. Grundbegriff des Evangeliums - Schlüssel christlichen Lebens, Freiburg im Br. 2012, where Card. Kasper developed his own teaching on mercy in an ample, systematic study.

91 Brat Roger z Taizé, Bóg może tylko kochać..., p. 60. 
it in his writings - is sent to be an instrument and sign of God's love and mercy. And here we come to the point to which Brother Roger was one of the first to draw our attention: how can the Church concretize God's love if she is divided in herself? For him, this is not just an ecumenical problem, but a real suffering of many Christians of different denominations because it is a denial of the nature and mission of the Church. The division of the Church for Brother Roger is a tragedy which is increased by the indifference of Christians who accept this condition. ${ }^{92}$ In this cry for unity he had the courage of a prophet who was ahead of his time. As a cure that would make it possible to truly restore the unity of the Church, he pointed to mercy, forgiving love:

Will Christians have a heart that is wide enough, a mind that is open enough, love that is fervent enough to discover this Gospel way of reconciliation without delay? [...] When Christians continue in great simplicity and infinite kindness of heart, when they carefully seek to discover the deep beauty of the human soul, they already begin to live in the communion that Christ gives. This communion, which is the Church, can regain credibility among young people if the Church becomes more transparent, seeking with all her soul to love and forgive. ${ }^{93}$

As we have already shown in the previous paragraph, ecumenism for Brother Roger is not so much theological disputes and findings as a reality written by one's life - a mission that opens new paths of reconciliation. This is his most important legacy not only for the Taizé Community, but also for the whole Church. ${ }^{94}$

And at this point, Cardinal Kasper poses an important question: can this path set out by Brother Roger be regarded today as a paradigm for ecumenism? Undoubtedly, the vocation of the founder of Taizé is something extraordinary a personal path inspired by the Holy Spirit at a particular moment in the history of the Church and the world ${ }^{95}$ and in this sense cannot be copied. However, the personal charism of the founder of the Order is no longer perceived in the Church as just some kind of private grace, but becomes something fundamental for a given community, and through it is realized as a gift for the entire Church. Thus, through the Taizé Community, Brother Roger's charism radiates to the whole of Christianity, and in this sense his legacy can be read as a discrete indication by the Holy Spirit of the future path to ecumenism. Today, after a wave of post-concil-

92 W. Kasper, Mercy and the Ecumenical Journey of Brother Roger..., p. 289-290. See also G. Hammann, op. cit., p. 23-24. Cf. Brat François, op. cit., p. 5-7.

93 Brat Roger z Taizé, Bóg może tylko kochać..., p. 60-61.

94 Cf. W. Kasper, Mercy and the Ecumenical Journey of Brother Roger..., p. 291.

95 Cf. D. Sattler, op. cit., p. 282-283. 
iar enthusiasm, ecumenism has reached such a point that, with the help of God's grace, it needs courageous personal decisions in order for reconciliation between the Churches to continue concretely. ${ }^{96}$ And the creator of Taizé showed with his life how to do this in a clear and irrevocable way, without denying one's own identity and without breaking up with anyone. For him, the basic method on this journey, as outlined above, is mercy. It is the cure of mercy and forgiveness that heals the wounds of divisions in the Church, and at the same time is not some form of "cheap grace." With this vision of the Church, which does not exclude anyone on the basis of this "method of mercy," Brother Roger remains in agreement with the line of teaching of the holy popes who supported him in his ecumenical vocation: John XXIII ${ }^{98}$ and John Paul II. ${ }^{99}$ Likewise, today Pope Francis, in guiding the Church, constantly opens the door of mercy for all. Therefore, Cardinal Kasper is convinced, seeing from the present perspective how great a gift God has given us in the person of Brother Roger, that as a Church we are invited to continue on this path of Christian reconciliation, which he has shown us with the witness of his life and teaching. ${ }^{100}$

\section{CONCLUSION - THE INSPIRING TOPICALITY OF BROTHER ROGER'S LEGACY}

This article in its form is only a certain theological sketch, which does not aspire to exhaust such a rich issue. Rather, as already indicated in the introduction, it is an invitation to explore more intensively what the founder of Taizé left to the Church. In conclusion, according to the structure of the above presentation, the following three essential components of this heritage, which form a certain harmonious whole, can be pointed out from today's perspective as permanently valid. First, it is a fully original form of Christian life in a monastic ecumenical community. This originality, in short, consists, on the Protestant side, in a return to

96 Cf. Brat François, op. cit., p. 21, 23.

97 Here it is worth recalling the source and understanding of this term and the distinction between "cheap" and "expensive" grace in contemporary theology - D. Bonhoeffer, Naśladowanie, transl. J. Kubaszczyk, Poznań 1997, p. 9-11.

98 In this context, it is important to recall the words spoken by this Pope at the beginning of the Second Vatican Council, to which Br. Roger referred: "The Church prefers to resort to the cure of mercy rather than to wave the weapon of austerity" - see Brat Roger z Taizé, Bóg może tylko kochać..., p. 66.

99 Cf. A. Dudek-Kowalska, Miłosierdzie jako oikonomia Kościoła. Na podstawie wybranych tekstów Magisterium Ecclesiae, "Teologia w Polsce" 13 (2019) 2, p. 217-218.

100 See more W. Kasper, Mercy and the Ecumenical Journey of Brother Roger..., p. 294-297. 
the model of monastic life before the division of the Church, and on the Catholic side, in the ecumenical composition of that community. Secondly, on the basis of this concrete experience of the Taizé Community, Brother Roger showed a deeply existential way of reconciliation of the divided Christians, based on building communion through the community of life, which preceded in a pioneering way the possibilities arising from the previous doctrinal arrangements. And thirdly, in his teaching, which, although not systematic in nature, he gave a clear outline, deeply rooted in the Bible, of a theology of forgiving love as the key to building the foundations for authentic reconciliation between the Churches.

To be open to the future, we should accept the suggestion of some authors that the Taizé Community, as a realization of Roger Schutz's vision, has something of poetry in it - it tries to grasp what is often only sensed, what is mainly spiritual intuition, or perhaps, to put it more biblically, it is a place to seek what the Holy Spirit tells the Church, and therefore has a certain prophetic character. ${ }^{101}$ This gives it a constantly creative dynamic, which allows it to develop the work of its founder and to set forth constantly new ways of reconciliation in the Church. Brother Roger's charism attests to the fact that for the fulfillment of Jesus' desire "that all be one" (Jn 17:21) the Holy Spirit breathes "where he wants" (Jn 3:8) and is not limited by human divisions in the Church. For the unity of the Church in its essence is the work of the Holy Spirit. ${ }^{102}$

It is also worth noting that the results presented here can be put into practice: Brother Roger's legacy can inspire in concrete terms the activities of our ecclesial communities on very different levels, not necessarily linked directly to ecumenism, but rather to the building of unity in the broader sense. Many visitors to Taizé experience discovering at a deeper level their own ecclesial identity through encounter with diversity. A well-understood unity does not consist in unification, but in the light of Paul's model of the Church as the Body of Christ, in mutual enrichment. John Paul II wrote in this context about a new method of ecumenical building of communion through the "exchange of gifts" between the Churches. ${ }^{103}$ Taizé, through its own example, teaches that such an essential means is simply to enable us to meet one another and discover diversity, not as what divides, but as what enriches. ${ }^{104}$

Brother Roger's witness of life and his writings are constantly a profound spiritual inspiration for many Christians of different denominations, and not only for the young, with whom we now mainly associate Taizé. For many of them, he is

101 Cf. D. Sattler, op. cit., p. 266; K. Scott, op. cit., p. 126-127.

102 See John Paul II, Encyclical Ut unum sint, Vatican 1995, No. 7, 102.

103 Ibidem, nr 57, 87.

104 See more Frère Alois, op. cit., p. 10-12. 
not only a spiritual authority, but even a saint - an ecumenical saint, beyond the divisions. ${ }^{105}$ When, therefore, from a certain distance, we judge the fruits of the life of the founder of Taizé in an evangelical way, it is above all necessary to point out here the hundreds of thousands of Christians who, by attending the meetings organized by this Community, inspired by the authenticity of his witness to the life of the Gospel, have created, throughout Europe, as well as on other continents, in the 80 years since the arrival of young Roger Schutz in this Burgundy village, an ecumenically sensitive "Taizé generation," embracing all Christian traditions.

\section{BIBLIOGRAPHY}

Bonhoeffer D., Naśladowanie, transl. J. Kubaszczyk, Poznań 1997.

Bonhoeffer D., Życie wspólne, transl. K. Wojtowicz, Kraków 2001.

Bóg. Cisza. Prostota. Brat Marek z Taizé w rozmowie z Piotrem Żyłką, Kraków 2019.

Bóg przyjmuje wszystkich. Brat Alois z Taizé odpowiada na pytania młodzieży, transl.

M. Cofta, Poznań 2009.

Brat Roger, Reguła. Listy i modlitwy [no place of publ.] 1981 [duplicator painting].

Brat Roger przeor Taizé, Niech twoje święto trwa bez końca. Zapiski (1969-1974), transl.

A. Szymanowski, Warszawa 1982.

Brat Roger z Taizé, Miłość ponad wszelka miłość. Źródła Wspólnoty z Taizé, transl.

Wspólnota z Taizé, Poznań 1991.

Brat Roger z Taizé, Jego miłość jest ogniem, transl. A. Foltańska, Katowice $1992^{2}$.

Brat Roger z Taizé, Źródła Taizé. Bóg chce naszego szczęścia, transl. Taizé, Poznań 2001.

Brat Roger z Taizé, U źródet radości. List 2004, transl. Taizé, Taizé 2004.

Brat Roger z Taizé, Bóg może tylko kochać, transl. M. Prussak, Warszawa 2005.

Brat François, Czy Chrystus jest podzielony?, transl. M. Prussak, Poznań 2012 [Zeszyty z Taizé 13].

Brother Alois Prior of Taizé, In Conclusion, in: Brother Roger 's Contribution to Theological

Thought. Acts of the International Colloquium Taizé, August 31 -September 5, 2015,

Taizé 2016, p. 299-300.

Brother Alois Prior of Taizé, Presentation, in: Brother Roger's Contribution to Theological

Thought. Acts of the International Colloquium Taizé, August 31 -September 5, 2015,

Taizé 2016, p. 11-12.

Brother Alois Prior of Taizé, What Is Distinctive about Taizé?, in: The Relevance of

a Religious or Monastic Vocation. Acts of the International Colloquium, Taizé, 5-12

July 2015, Taizé 2016, p. 13-19.

Clément O., Taizé, szukanie sensu życia, transl. M. Prussak, Poznań 1999.

105 See John Paul II, Ut unum sint..., nr 84. Cf. D. Sattler, op. cit., p. 266. 
Dudek-Kowalska A., Miłosierdzie jako oikonomia Kościoła. Na podstawie wybranych tekstów Magisterium Ecclesiae, “Teologia w Polsce” 13 (2019) 2, p. 201-222.

Escaffit J.-C., Rasiwala M., Historia Taizé, transl. K. i K. Pruscy, Warszawa 2009.

Fox H., Die Theologie Max Thurians, Trier 1971.

Frère Alois, "Die Leidenschaft für die Einheit des Leibes Christi". Der Weg der Einheit, wie er in Taizé gelebt wird, Taizé 2012 [Hefte aus Taizé 17].

Frère Roger de Taizé, Fleurissent les déserts du cour, Taizé 1982.

Frère Roger de Taizé, À la joie je t’invite. Fragments inédits 1940-1963, Taizé 2012 [Les écrits de frère Roger, v. 2].

Froniewski J, Teologiczne znaczenie wkładu Maxa Thuriana w przygotowanie "Dokumentu z Limy (BEM)" w zakresie eucharystycznego charakteru anamnezy (z pozycji 30 lat recepcji Dokumentu), "Wrocławski Przegląd Teologiczny” 20 (2012) 2, p. 83-98.

Grygiel M., Taizé, in: Encyklopedia katolicka, vol. 19, Lublin 2013, c. 448.

Hammann G., Did Brother Roger Have a Theology?, in: Brother Roger's Contribution to Theological Thought. Acts of the International Colloquium Taizé, August 31 September 5, 2015, Taizé 2016, p. 17-28.

Hardt M., Thurian Max, in: Personenlexikon Ökumene, Hg. J. Ernesti, W. Thönissen, Freiburg in. Br. 2010, p. 225-226.

Höglauer J., Der Einfluss von Taizé auf die Spiritualität Jugendlicher. Eine empirische Untersuchung, Berlin 2016.

John Paul II, Encyklika "Ut unum sint”, Vatican 1995.

Kasper W., That They May All Be One. The Call to Unity, London-New York 2004.

Kasper W., A Handbook of Spiritual Ecumenism, New York $2008^{3}$.

Kasper W., Barmherzigkeit. Grundbegriff des Evangeliums - Schlüssel christlichen Lebens, Freiburg im Br. 2012.

Kasper W., Mercy and the Ecumenical Journey of Brother Roger, in: Brother Roger's Contribution to Theological Thought. Acts of the International Colloquium Taizé, August 31 - September 5, 2015, Taizé 2016, p. 285-297.

Kopp S., Liturgie und Ökumene aus katholischer Perspektive, "Catholica" 72 (2018) 1-2, p. $120-133$.

Koza S.J., Schutz Roger, in: Encyklopedia katolicka, vol. 17, Lublin 2012, c. 1298-1299.

Księgi Wyznaniowe Kościoła Luterańskiego, Bielsko-Biała 1999.

Laplane S., Frère Roger de Taizé. Avec presque rien..., Paris 2015.

Luther M., Ein Urteil Luthers über die Klostergelübde, in: Luther deutsch. Die Werke Martin Luthers in neuer Auswahl für die Gegenwart, Hg. K. Aland, Bd. 2, Göttingen 1991, p. 313-322.

Łopalewski A., Taizé przypowieścia o komunii i pojednaniu. Formacja chrześcijańska wspólnoty z Taizé, Lublin 2011. 
Oeldemann J., Schutz Roger, in: Personenlexikon Ökumene, Hg. J. Ernesti, W. Thönissen, Freiburg im Br. 2010, p. 206-208.

Papież Jan Pawet II w Taizé, Taizé 1986 (mimeograph).

Paupert J.-M., Taizé i Kościót jutra, transl. A. Pilorz, Warszawa 1969.

Préparer le concile des jeunes. Audacieuse aventure, Taizé 1973.

Reguła zwana „małe źródło” Taizé, Taizé [no year of issue] (mimeograph).

Sattler D., Contributions by Brother Roger Schutz to Theology, in: Brother Roger's Contribution to Theological Thought. Acts of the International Colloquium Taizé, August 31 - September 5, 2015, Taizé 2016, p. 265-284.

Schlumberger L., Can One Be Protestant and a Monk?, in: Brother Roger's Contribution to Theological Thought. Acts of the International Colloquium Taizé, August 31 September 5, 2015, Taizé 2016, p. 89-104.

Scott K., Experiencing and Thinking Jesus, in: Brother Roger's Contribution to Theological Thought. Acts of the International Colloquium Taizé, August 31 -September 5, 2015, Taizé 2016, p. 119-130.

Sigov C., Vulnerable Trust and the "New Song” of Taizé, in: Brother Roger's Contribution to Theological Thought. Acts of the International Colloquium Taizé, August 31 September 5, 2015, Taizé 2016, p. 175-189.

Skowronek A., Odkrywanie jedności, Warszawa 1988.

Wybrać miłość. Brat Roger z Taizé 1915-2005, transl. M. Prussak, Poznań 2008.

Websites:

Brat Roger, Listy do młodych (wykaz) [Letters to the youth], https://pl.wikipedia.org/wiki/ Roger_Louis_Sch\%C3\%BCtz-Marsauche [access: 13.04.20].

Brat Roger, Bibliografia wydanych dzieł zebranych w j. francuskim [bibliography of the collected works in French], http://www.taize.fr/pl_article10857.html?territ=10\&category=1\&lang=pl [access: 13.04.20].

Keywords: Roger Schutz, Brother Roger of Taizé, Taizé Community, ecumenism, ecumenical theology, unity of the Church

\section{AKTUALNOŚĆ DZIEDZICTWA DUCHOWEGO I TEOLOGII BRATA ROGERA Z TAIZÉ}

\section{Streszczenie}

W tym roku przeżyliśmy we Wrocławiu Europejskie Spotkanie Młodych organizowane przez Wspólnotę z Taizé. To wielkie wydarzenie duchowe jest okazją do głębszej refleksji nad znaczeniem dziedzictwa brata Rogera z Taizé dla współczesnego Kościoła. Autor 
za punkt wyjścia tej analizy przyjął tło biograficzne, które pozwoli czytelnikowi uchwycić kontekst życiowy specyfiki poszukiwań ekumenicznych Rogera Schutza. Następnie w kolejnych punktach opisuje trzy zasadnicze elementy dziedzictwa brata Rogera, które są stale inspirującym darem dla Kościoła na drodze budowania jedności. Po pierwsze, jest to w pełni oryginalna forma życia chrześcijańskiego w monastycznej wspólnocie ekumenicznej. Po drugie, na bazie tego konkretnego doświadczenia Wspólnoty z Taizé brat Roger wskazał głęboko egzystencjalną drogę budowania jedności podzielonych chrześcijan. I po trzecie, w swoim nauczaniu naszkicował teologię przebaczającej miłości jako klucz do budowania pojednania między Kościołami. Bez wątpienia najbardziej spektakularnym owocem jego ewangelicznego życia są rzesze młodzieży z różnych Kościołów chrześcijańskich, które niezmiennie od dziesięcioleci gromadzą się wokół Wspólnoty z Taizé.

Słowa kluczowe: Roger Schutz, brat Roger z Taizé, Wspólnota z Taizé, ekumenizm, teologia ekumeniczna, jedność Kościoła 